Discussion Paper No. 08-134

The Impact of Innovation on Employment in Small and Medium Enterprises with Different Growth Rates

Volker Zimmermann

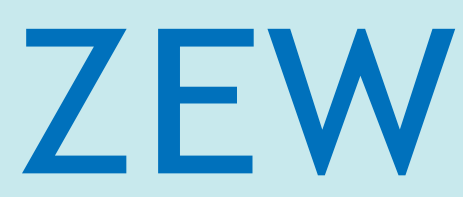

Zentrum für Europäische Wirtschaftsforschung $\mathrm{GmbH}$

Centre for European

Economic Research 
Discussion Paper No. 08-134

\title{
The Impact of Innovation on Employment in Small and Medium Enterprises with Different Growth Rates
}

\author{
Volker Zimmermann
}

Download this ZEW Discussion Paper from our ftp server:

ftp://ftp.zew.de/pub/zew-docs/dp/dp08134.pdf

Die Discussion Papers dienen einer möglichst schnellen Verbreitung von neueren Forschungsarbeiten des ZEW. Die Beiträge liegen in alleiniger Verantwortung der Autoren und stellen nicht notwendigerweise die Meinung des ZEW dar.

Discussion Papers are intended to make results of ZEW research promptly available to other economists in order to encourage discussion and suggestions for revisions. The authors are solely responsible for the contents which do not necessarily represent the opinion of the ZEW. 


\section{Non-technical Summary}

Using information on almost 12.000 firms this article examines the impact of innovation on employment growth in innovating small and medium enterprises. In contrast to existing studies, which typically use the least squares estimation technique, quantile regressions were carried out to analyse the data. This method allows one to examine the effects of innovation at any desired point in the distribution function - for example, in firms experiencing positive or negative growth - providing a more complete picture of the relationship between innovation and employment growth than by the standard method of viewing deviations in the average effect.

The key finding of the study is that innovation has a positive effect on employment in both growing and shrinking small and medium enterprises. In addition, innovation has a much stronger impact on employee headcounts in companies that are already experiencing strong growth than in their slower growing or shrinking counterparts. When differentiating between product and process innovations, the analysis shows that the introduction of new or improved processes has a larger impact on employment than product innovations. Thus, positive employment effects of innovations are not restricted to narrow segments of the economy. Economic policy aimed at bolstering the innovative strength of firms is thus a strong encouragement to employment on a broad basis. 


\section{Das Wichtigste in Kürze (Summary in German)}

Dieser Beitrag untersucht anhand einer Stichprobe von rund 12.000 kleinen und mittleren Unternehmen die Wirkung von Innovationen auf das Beschäftigtenwachstum. Abweichend von vorliegenden Studien wird dabei nicht auf die üblicherweise verwendete KleinstQuadrate-Regression zurückgegriffen, sondern es werden Quantilsregressionen durchgeführt. Diese Methode erlaubt es, die Wirkung von Innovationen in unterschiedlich schnell wachsenden oder auch schrumpfenden Unternehmen zu untersuchen und somit ein vollständigeres Bild des Zusammenhangs zwischen der Implementierung von Innovationen und dem Beschäftigungswachstum in Unternehmen als bei der sonst üblichen Betrachtung mittlerer Effekte zu erhalten.

Zentrales Ergebnis der Untersuchung ist, dass von Innovationen sowohl in schrumpfenden als auch in wachsenden kleinen und mittleren Unternehmen positive Beschäftigungseffekte ausgehen. Dabei kann in Unternehmen, die ohnehin bereits wachsen, für Innovationen eine deutlich stärkere Wirkung auf die Beschäftigtenzahl ermittelt werden, als in Unternehmen, für die dies nicht gilt. Die Unterscheidung in Produkt- und Prozessinnovationen belegt, dass zumindest bei einer vergleichsweise kurzfristigen Betrachtung von neuen bzw. verbesserten Prozessen eine höhere Beschäftigungswirkung ausgeht als von Neuerungen in der Produktpalette. Positive Beschäftigungswirkungen von Innovationen sind somit nicht nur in engen Marktsegmenten zu erwarten, sondern zeigen sich über eine weite Bandbreite kleiner und mittlerer Unternehmen. Eine Stärkung der Innovationskraft von Unternehmen entfaltet damit bezüglich der Beschäftigungswirkung eine starke Breitenwirkung. 


\title{
The Impact of Innovation on Employment in Small and Medium Enterprises with different Growth Rates
}

\author{
Volker Zimmermann ${ }^{1}$ \\ KfW Bankengruppe, Frankfurt, Germany
}

\begin{abstract}
This article examines the impact of innovation on employment growth in innovating small and medium enterprises using a quantile regression approach. The key findings are that innovation has a positive effect on employment in both growing and shrinking firms. The impact of innovation on employee headcounts is much stronger in companies that are already experiencing strong growth than in their slower growing or shrinking counterparts. Thus, positive employment effects of innovations are not restricted to narrow segments of the economy. Economic policy aimed at bolstering the innovative strength of firms is thus a strong encouragement to employment on a broad basis.
\end{abstract}

Keywords: Labour demand, innovation, small and medium enterprises

JEL-Classification: J23, O33, C21

Corresponding author:

Volker Zimmermann

volker.zimmermann@kfw.de

Phone: +49/69/7431-3725, Fax: +49/69/7431-3503

KfW Bankengruppe

Volkswirtschaftliche Abteilung

Palmengartenstr. 5-9, 60325 Frankfurt, Germany

${ }^{1}$ The author is exlcusively responsible for the contents of this article, which does not necessarily represent the views of KfW Bankengruppe. 


\section{Introduction}

The impact of innovation and technological progress on growth, wealth, and above all on employment is a topic of inquiry nearly as old as modern economics. As early as 1821, Ricardo revised his assessment of the contribution made by innovation to the general welfare and at last voiced pessimism about the impact of technological change on employment (König 1997). In the 1980s, as well, technological development was viewed as a contributing factor to rising unemployment (Welsh 2006). Today, by contrast, high expectations are attached to technological development and innovation as a key driver of national economic competitiveness and growth, particularly by economic policy makers. New technologies are now viewed as a "basis for prosperity and jobs" (BMBF 2007: 8).

As theoretical models are unable to precisely define the effect of innovation on employment, this interrelationship has also been the subject of a great deal of empirical research in recent years (Zimmermann 2008, Lachenmaier 2007, Lachenmaier and Rottmann 2007, Peters 2006, among others). Yet all of the aforecited studies make use of the least squares regression technique, and thus aim at identifying differences in the mean of (conditional) growth distributions between innovating and non-innovating companies. Possible divergent effects from innovation at other points on the distribution can not be analyzed with this estimation technique. With a view to economic policy formation, however, the (conditional) mean in employment growth triggered by innovation is not the only subject of interest. Policy makers would also benefit from knowing if and to what extent this employment effect differs in firms with various rates of growth so that additional conclusions can be drawn about the scope of the impact exerted by innovations. In the present study, a quantile regression method is used. This allows the effects of innovation to be investigated at any point on the distribution - for example, in firms experiencing negative or positive growth.

An additional focus of this study is on small and medium enterprises (SMEs). While SMEs employ the majority of Germany's work force, and also play an important role in Germany's national innovation system, accounting for over a quarter of all R\&D expenditures and almost half of all R\&D expenditures in knowledge-intensive business services (Rammer et al. 2006), in existing studies SMEs are usually only mentioned peripherally or (at least partially) omitted.

This study concludes that innovation has a positive effect on employment in both growing and shrinking SMEs. In addition, innovation has a much stronger impact on employee headcounts in companies that are already experiencing strong growth than in their slower growing or shrinking counterparts. When differentiating between product and process innovations, our analysis shows (at least from a relatively short-term perspective) that the introduction of new or improved processes has a larger impact on employment than the introduction of new or improved products. 
This paper is organized as follows: In the second section, theoretical considerations pertaining to the effects of innovation on employment are discussed. Section three presents the empirical results and section 4 summarises the key findings of the study.

\section{Conceptual Background}

In order to analyse the effects of innovation on employment, a difference is generally drawn between process and product innovations. The term 'product innovation' encompasses the creation and implementation of new or qualitatively improved products. 'Process innovation', by contrast, refers to the intracompany deployment of new or improved manufacturing or processing technologies and techniques (Stoneman 1983). ${ }^{1}$ This differentiation is important, as each type of innovation influences employment through different channels (Katsoulacos 1986, Lehner et al. 1998).

The starting point of any study dealing with the impact of innovation on employment is the labour demand function at the firm level. The labour demand of a firm $i$ is usually represented in theoretical models as dependent on the factors technology $T$, product quality $Q$, as well as additional observable variables $X$ and non-observable variables $\lambda$ (Zimmermann 1987, König et al. 1995, Rottmann and Ruschinski 1997, Smolny and Schneeweis 1999, as well as Lachenmaier and Rottmann 2007, among others)

$$
L_{i}=f\left(T_{i}, Q_{i}, X_{i}, \lambda_{i}\right) \text {, }
$$

where changes in product quality are viewed as product innovations, and changes in manufacturing processes are seen as process innovations.

Changed levels of employment due to higher productivity with unchanged output are usually defined as a 'direct' effect of process innovation on a firm's labour demand. ${ }^{2}$ Therefore, it can generally be expected that reduced labour demand will result as a direct effect of a process innovation. ${ }^{3}$ However, cost reductions due to process innovations can be used for price reductions, which can in turn increase demand for the company's product(s). Increased production is associated with an increase in employment. ${ }^{4}$ Whether this indirect effect (which is based on a turnover change) outweighs the direct productivity effect (which generally reduces labour demand) depends essentially on the extent of the price reduction as well as the demand reaction to reduced prices.

\footnotetext{
${ }^{1}$ The division between process and product innovations was originally made by Schumpeter (1912), who, in addition to product and process innovations (including organizational changes), also differentiated between the exploitation of new markets, new sources of raw materials, and alternate input products as types of innovation.

${ }^{2}$ Changes in manufacturing processes need not be implemented necessarily with the goal of increasing labour productivity, however. Additional possible goals of process innovation include the reduction of energy/material consumption and strengthening environmental protections, among others.

${ }^{3}$ A positive direct employment effect resulting from process innovations is also conceivable, however. This occurs when a process innovation increases labour productivity to such an extent that the substitution of capital for labour is advantageous for a company (Katsoulacos 1986).

${ }^{4}$ This increase in employment within a firm can also take place at a production stage up or downstream from the process innovation.
} 
With respect to product innovations, often the only effects on employment taken into consideration are effects based on demand changes triggered by new or improved products (or services). This approach implies that product innovations only have an effect on employment when new or improved products are commercially successful and generate turnover after their release by the firm. A strong increase in demand can therefore be expected first and foremost when new products are released that are novelties on the market, as the entire market demand for such new products is captured by the innovating company. ${ }^{5}$

This effect is smaller when the innovating firm initially enjoys a monopolistic position or (at least) high market share for a given product and exploits this situation with a higher product price in order to maximize profits. If the foregoing is the case, output and associated labour demand are comparatively small at first, and only rise with the emergence of competitors (Gaskins 1971). This positive direct employment effect is accompanied by an 'indirect' negative (substitution) effect when the product replaces an old product of the company. ${ }^{6}$ The indirect effect of a product innovation can also be positive, however, when the product is used in tandem with an already existing company product.

From a theoretical perspective, therefore, the effect of product and process innovations on a company's employment is indeterminate. Rather, one should expect that, as a result of counteracting effects, innovation will produce alternative outcomes depending on the concrete characteristics of the firm, in conjunction with auxiliary factors. In addition to a divergence between product and process innovations, divergent effects resulting from innovation can also be expected relative to a firm's rate of growth, whether positive or negative.

It is possible, for example, that the type and quality of innovation varies in companies with alternate growth rates, in turn leading to divergent employment effects. If a firm is experiencing strong growth, this could be an indicator that the firm is active in a new and expanding market in which product innovations regularly take the form of market novelties (Utterback and Abernathy 1975, Gort and Klepper 1982). This can lead to stronger demand changes for the innovating firm than the release of products which are not novelties on the market. In addition, it can be assumed that expanding firms generally release 'aggressive' innovations more often: product innovations are aimed at tapping new markets or expanding the firm's product range, to name two examples, while process innovations are more often related to the release of new products (Rammer et al. 2004).

Furthermore, it is also possible that stronger growth is ultimately reflective of better management. In this way, it could be that fast-growing, successful firms are also more likely to develop successful innovations. It follows from this line of reasoning that, among the companies that are shedding employees, the percentage of non-successful innovating firms is

\footnotetext{
${ }^{5}$ An analogous effect can also be expected in the case of process innovations, when the firm in question is the first to implement a given innovation and is also the first to enact price reductions.

${ }^{6}$ This discussion of the direct and indirect effects of product innovations makes use of the common definitions used as of late; see, for example, Lehner et al. (1998), or Peters (2003). As an alternative to this definition, the direct effect of product innovations - similar to the definition concerning process innovations - can be defined as a higher requirement for labour input at constant output (due to higher product quality, for example). From this approach the described demand effects triggered by product innovations are thus downstream 'indirect' effects; see Rottmann and Flaig (1999), König et al. (1995), or Zimmermann (1987) for a more elaborate illustration.
} 
much higher - because new products are not accepted by the market or new processes do not result in the desired cost reductions (Freel 2000). This explanation is of importance, as the standard innovation indicator which is also used in this study only designates that innovations have been implemented at a firm, but not if these innovations have been successful.

Taken together, these considerations indicate that the growth rate in high-growth firms should increase even further through innovation. In slow-growing or shrinking firms, by contrast, the stimulus to growth provided by innovation may be weaker or even non-existent.

\section{$3 \quad$ Empirical Investigation}

\subsection{Estimation Strategy}

In order to investigate the impact of innovation on employment at a firm, the labour demand function is formulated as a dynamic equation. The logarithm of the equation (1) is taken and differences are formed, yielding the following

$$
\Delta \ln L_{i}=\varepsilon_{L T} \Delta \ln T_{i}+\varepsilon_{L Q} \Delta \ln Q_{i}+\varepsilon_{L X} \Delta \ln X_{i},
$$

where $\varepsilon$ represents the respective elasticities of labour demand. The advantage of forming differences lies in the elimination of unobserved, time-constant heterogeneity. The changes in production technology or product quality are interpreted as process innovation $P Z$ or product innovation $P D .^{7}$ Permitting additional control variables $X$ we get the following regression equation:

$$
\Delta \ln Y_{i}=\alpha+\beta_{1} P Z_{i}+\beta_{2} P D_{i}+\beta_{3} X_{i}+u_{i} .
$$

The least squares estimation technique is typically used to analyse the impact of innovation in terms of a percentage change in employment within a firm. This method investigates if and to what extent the mean of the (conditional) change in employment differs between innovating and non-innovating firms. The quantile regressions used first and foremost in this study permit the impact of innovation to be measured in each desired quantile of the changein-employment distribution (which is conditional on the explanatory variables) (Koeneker and Bassett 1978). This allows the hypotheses presented in section 2 to be investigated at each point in the distribution, for example in growing or shrinking firms. The quantile regressions thus deliver a more comprehensive picture of the relationship between innovation and employment. $^{8}$

\footnotetext{
${ }^{7}$ Key determinants of employment in a firm that can be derived from the labour demand function are the factor prices for labour and capital. Both aspects could not be taken into consideration in the present study, as information on these factors was available in the data pool only for a portion of the surveyed firms.

${ }^{8}$ Estimates have been made with the STATA program package.
} 


\subsection{Data Description}

The analysis is based on the $K f W$-Mittelstandspanel, the first and only representative longitudinal database for all small and medium enterprises in Germany (i.e., all firms with an annual turnover of up to 500 million euros). In particular, firms with fewer than five employees are included in the database, which, according to calculations made with the $K f W$ Mittelstandspanel, represent approximately $80 \%$ of all small and medium enterprises. The $K f W$-Mittelstandspanel conducts a written survey on an annual basis. A particular emphasis is placed on collecting data on business development, investment activities, and financing. In addition, information is collected in individual waves on special topics of interest (Reize 2007). In this way, in 2003, 2005, and 2006, data were collected on firms' innovation activities. In total, approximately 12,000 observations from these three data-collection waves were used for the following analysis.

The following paragraphs describe how the variables taken into account are defined. Logarithmic differences can be understood as an approximation of growth rates, so that the percentage growth in a firm's employment is used as the variable to be explained. In contradistinction to the established definition in empirical research (Evans 1987), in this study the annual employment growth rate is not used, but rather a two-year average. This was done due to the lack of variation in the dependent variable that results when the data for small and medium enterprises is viewed on an annual basis. ${ }^{9}$ The employment growth rate of a firm $i$ for a time period $t$ is defined as

$$
w_{i t}=\frac{L_{i t}-L_{i t-2}}{2 L_{i t-2}},
$$

where $L_{i t}$ stands for the number of employees on 31 December of year $t$ at a firm. When calculating the number of employees in a firm, owners who exercise an active management role as well as full- and part-time employees were counted (two part-time employees were weighted as one full-time equivalent). The average growth in employment witnessed at the firms included in this study was $4.3 \%$; median growth was $0 \%$ (see Table 1 ).

Table 1: Distribution of the employment growth

\begin{tabular}{|c|c|c|c|c|c|c|}
\hline & Mean & $\begin{array}{c}10 \% \\
\text { quantile }\end{array}$ & $\begin{array}{c}25 \% \\
\text { quantile }\end{array}$ & $\begin{array}{c}50 \% \\
\text { quantile }\end{array}$ & $\begin{array}{c}75 \% \\
\text { quantile }\end{array}$ & $\begin{array}{c}90 \% \\
\text { quantile }\end{array}$ \\
\hline $\begin{array}{c}\text { Employment growth rate } \\
\text { (in \%) }\end{array}$ & 4.3 & -11.5 & -4.8 & 0.0 & 8.3 & 20.0 \\
\hline
\end{tabular}

With regard to firms' innovation activities, the KfW-Mittelstandspanel also collects data on whether product or process innovations were introduced in year $t-2$, or in the previous two years. Products or processes are classified as innovations if they are new or exhibit distinct improvements over the products or processes for the innovating firm. Approximately 55\% of

\footnotetext{
${ }^{9}$ For $30 \%$ of firms no change in employment was observed on an annual basis, which could lead to problems in the quantile regressions. When employment was viewed on a two-year basis, the percentage of companies exhibiting no change was only approx. 13\%.
} 
the surveyed firms introduced innovations on the whole in the identified time frame; $34 \%$ of firms changed their production processes, and $46 \%$ released new products.

Additional control variables are the size and age ${ }^{10}$ of the firm, the percentage of turnover earned abroad, the legal form of the firm as well as gross value added at the industry level. ${ }^{11}$ Average gross value added is calculated over the time period $t-2$ to $t-5$, the same time period for which data was collected on innovation activities. All additional control variables relate to the year $t-2$. Furthermore, in order to control for the structure of the acquired data, the region in which the firm is based (former West vs. former East Germany), the firm's receipt of state subsidies (subsidised vs. non-subsidised) and the data collection wave are also taken into consideration. See table 2 in the appendix for descriptive statistics.

\subsection{Regression Results}

Tables 3 and 4 in the appendix provide the regression results for the quantile regressions in the $10 \%, 25 \%, 50 \%, 75 \%$, and $90 \%$ quantiles as well as for the least squares regression that was additionally carried out. The least squares regression shows the expected results for the control variables. The surveyed firms grow slower (in percent) as the size and age of the firm increase, while companies with a larger share of exports and firms that are active in a highgrowth industry grow faster. A positive effect on employment growth is determined for innovations on the whole as well as for process and product innovations. The results of this study thus corroborate the previously mentioned recent studies on the employment effects of innovation (Zimmermann 2008, Lachenmaier and Rottmann 2007). With a $\mathrm{R}^{2}$ of around 7\% the goodness-of-fit is within the usual boundaries for studies of this type.

With regard to the control variable, the quantile regressions also show that fast-growing and fast-shrinking small and medium enterprises benefit in particular from a strong growth dynamic in their industry, whereas firms in the mid-range of the distribution are influenced to a lesser extent by the industry growth dynamic. A similar relationship - although considerably less pronounced - is witnessed for the relative share of turnover earned by a company abroad. The age and size of a firm, by contrast, have a dampening effect on employment growth the higher the quantile viewed. Overall, the lower-range quantile regressions display a worse goodness-of-fit than the estimations concerning the quantiles in the upper part of the distribution. As one approaches the median regression the goodness-of-fit decreases at first. This is probably related to the fact that the observations without a change in employment (which constitute 13\% of the observations) could all be found just below and at the median.

Figures 1 and 2 display the effects of the various innovation indicators for the supplementary quantile regressions for the quantiles $5 \%$ to $95 \% .^{12}$ As figure 1 shows, with the exception of the lower edge of the distribution, innovation exercises a positive influence

\footnotetext{
10 The logarithm of both variables is used in the study.

${ }^{11}$ The EU's NACE classification system was used to identify the industry in which each firm is active (at the 3digit level).

12 The results for the quantile regressions above the $95 \%$ quantile and below the $5 \%$ quantile are not displayed, as the point estimators are calculated with increasing uncertainty. This is shown by the increasing width of the confidence intervals in figure 1.
} 
on employment growth across all quantiles, regardless of the nature of the innovation (i.e., whether process or product). This effect is between 0.5 and 1 percentage points for the quantiles below the median. From approximately the middle of the distribution upward, the impact of innovation on employment growth increases considerably to between 1.5 and 2 percentage points. As the conditional employment growth rate in this range was positive for the surveyed firms, it can be concluded that innovations exercise a considerably stronger effect on the number of employees in growing firms in comparison to firms experiencing declining or stagnating growth. This observation thus confirms the hypotheses presented in section 2, by which innovation should have a stronger employment effect in expanding firms than in other firms.

Figure 1: Impact of innovation on employment growth in SMEs

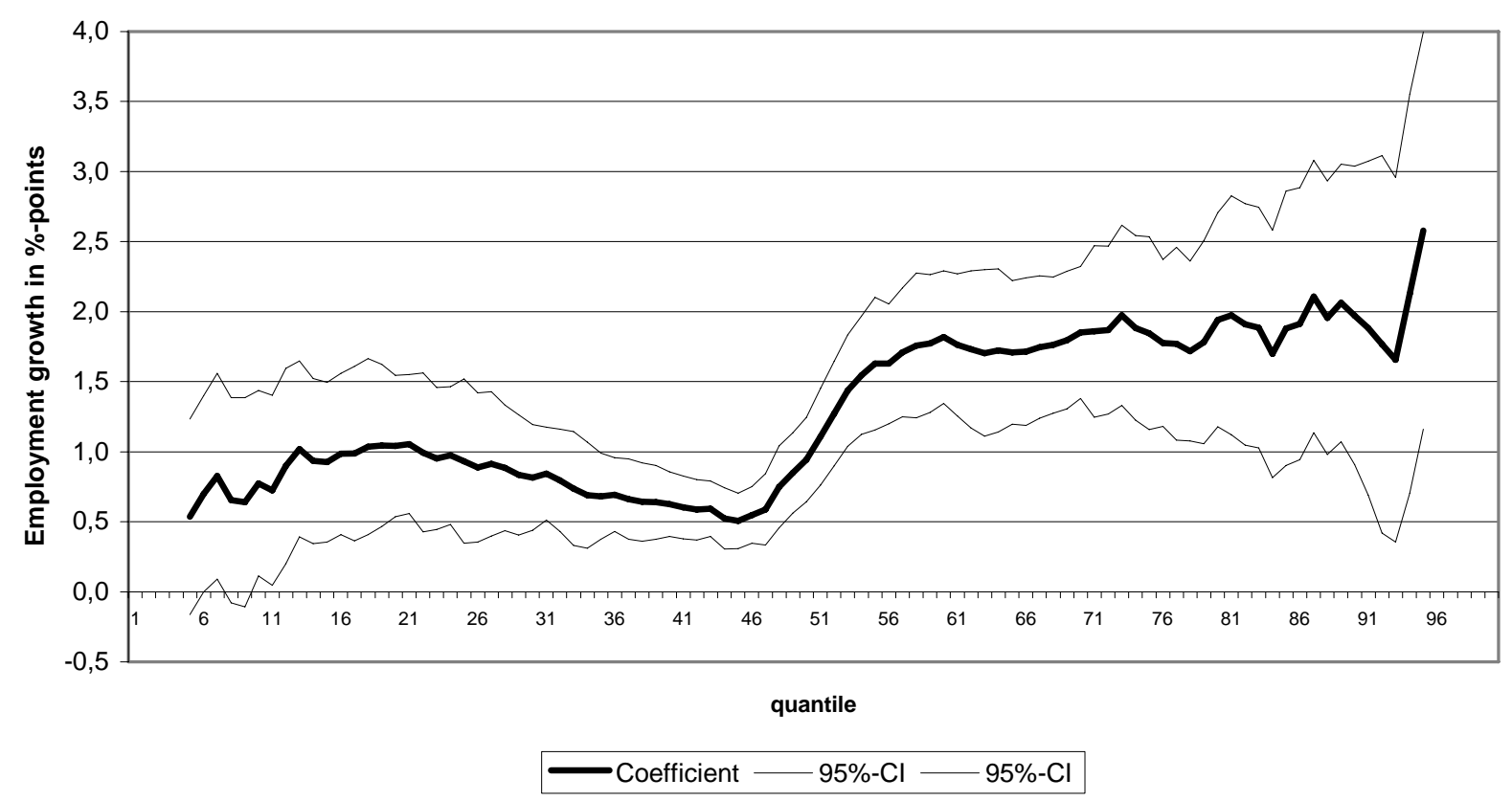

Figure 2 also confirms the findings when process and product innovations are distinguished. A positive effect on employment growth can be determined over the entire distribution for both process and product innovations. This effect is stronger in growing firms. This reveals that the lower impact of innovations on the whole in firms from the lower part of the distribution - as shown in figure 1 - is not due to different types of innovations (with regard to new products vs. new processes) in firms experiencing positive or negative growth. Yet product innovations only exercise a weakly significant effect on employment growth in the quantiles below the median. In these quantiles the lower range of the $95 \%$ confidence interval swings around the zero line. Furthermore, over the entire distribution for process innovations the coefficients indicate a higher impact on employment growth than for product innovations. The 95\% confidence intervals displayed in figure 2 show that the divergence in the regression coefficients is partially significant in a statistical sense or nearly reaches the threshold for significance. 
Figure 2: Impact of process and product innovation on employment growth in SMEs
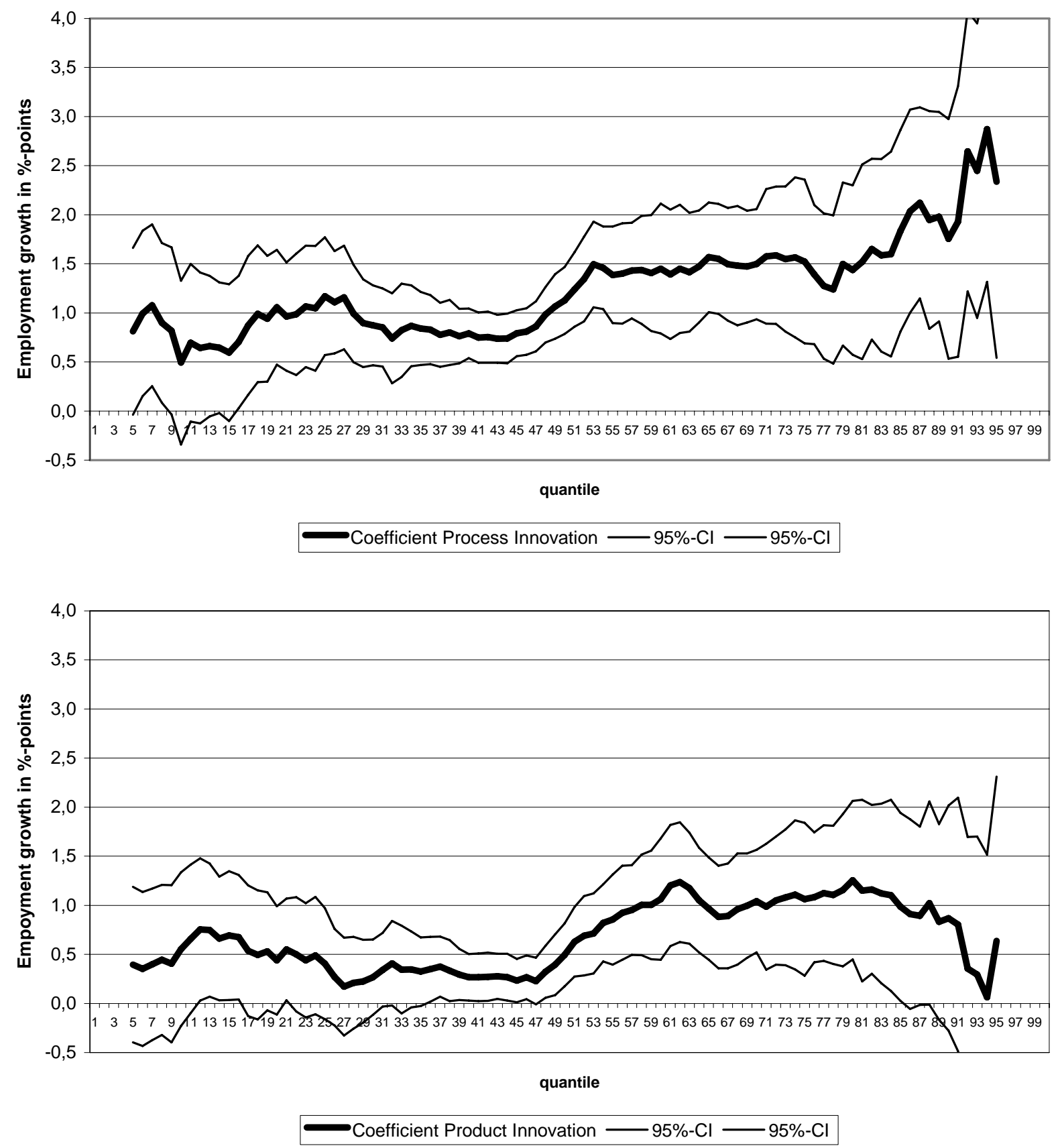

As described in section 2 from a theoretical point of view it is unclear whether a product or a process innovation should have a higher impact on employment. The lower impact of product innovation on employee headcounts which seems to be witnessed here could be attributable to this study's short-term focus. If time is required for a new product to establish itself commercially, benefits may take time to accrue. In the case of process innovations that allow immediate price reductions, however, expansive effects on employment would be measurable earlier on. 


\section{$4 \quad$ Conclusions}

This article examines the impact of innovation on employment growth in innovating small and medium enterprises. In contrast to existing studies, which typically use the least squares estimation technique, quantile regressions were carried out to analyse the data. This method allows to examine the effects of innovation at any desired point in the distribution function for example, in firms experiencing positive or negative growth - providing a more complete picture of the relationship between innovation and employment growth than is afforded by the standard method of viewing deviations in the average effect.

The key finding of the study is that innovation has a positive effect on employment in both growing and shrinking small and medium enterprises. The impact of innovation on employment growth is thus broad in scope. Furthermore, innovation has a much stronger impact on the number of employees in firms already experiencing strong growth than in their slower growing or shrinking counterparts. One explanation for this finding is that innovations in expanding firms are more 'aggressive' in nature and thus have stronger effects on demand and employment. Within the segment of non-growing firms, it is also possible that a larger percentage of firms are less successful commercially and that their innovations fail with greater frequency. When differentiating between product and process innovations, the analysis shows (at least from a relatively short-term perspective) that the introduction of new or improved processes has a larger impact on employment than the introduction of new or improved products.

Economic policy makers look to innovation and technological progress as the key to the creation of new jobs in the competitive industries of the future. As this study demonstrates, the positive employment effects of innovation are not restricted to narrow segments of the economy. They are wide in scope, and can be observed in both expanding and shrinking small and medium enterprises. Economic policy aimed at bolstering the innovative strength of firms is thus a strong encouragement to employment on a broad basis and can contribute to reducing Germany’s persistently high unemployment rate.

\section{$5 \quad$ References}

BMBF (Ed.) (2007), Die Hightech-Strategie für Deutschland - Erster Fortschrittsbericht.

Evans, D. (1987), Tests of Alternative Theories of Firm Growth, Journal of Political Economy 95 (4): 657-674.

Freel, M.S. (2000), Do Small Innovating Firms Outperform Non-Innovators? Small Business Economics 14: pp. 195-210.

Gaskins, D.W. (1971), Dynamic Limit Pricing: Optimal Pricing Under Threat of Entry, Journal of Economic Theory 3: pp. 306-322. 
Gort, M., S Klepper (1982), Time paths in the diffusion of product innovations, Economic Journal 92, pp. 630-653.

Huber, P.J. (1967), “The behaviour of maximum likelihood estimates under non-standard conditions”, Proceedings of the Fifth Berkeley Symposium on Mathematical Statistics and Probability 1: 221-233.

Katsoulacos, Y.S. (1986), The Employment Effect of Technical Change, Harvester, Brighton.

Koeneker, R.; G. Bassett, (1978), Regression Quantiles. Econometrica 46: 33-50.

König, H. (1997), Innovation und Beschäftigung, Zur Entwicklung der Arbeitsteilung in Europa. pp. 149-176 in: H.-.J. Vosgerau (Ed.), Zentrum und Peripherie - Duncker \& Humblot, Berlin.

König, H., H. Buscher, G. Licht (1995), Employment, Investment and Innovation at the Firm Level, OECD Jobs Study, Investment, Productivity and Employment, Paris

Lachenmaier, S., H. Rottmann (2007), Employment Effects of Innovation at the Firm Level, Jahrbücher für Nationalökonomie und Statistik 227/3: pp. 254-272.

Lachenmaier, S. (2007), Effects of Innovation on Firm Performance, ifo-Beiträge zur Wirtschaftsforschung 28, Munich.

Lehner, H., M. Baethge, J. Kühl, F. Stille (1998), Beschäftigung durch Innovation. Eine Literaturstudie, Rainer Hampp Verlag, Munich.

Peters, B. (2006), Innovationen und ihre Wirkung auf die Beschäftigung in KMU S. 124 153, in: R. Aber, H.H. Bass, R. Ernst-Siebert (Eds.), Kleine und mitte große Unternehmen im globalen Innovationswettbewerb. Technikgestaltung, Internationalisierungsstrategien, Beschäftigungsschaffung, Rainer Hampp Verlag, München und Mering.

Peters, B. (2003), Innovation und Beschäftigung, pp. 113-148 in: N. Janz G. Licht, (Eds.), Innovationsforschung heute, Baden-Baden.

Rammer, C., H. Penzkofer, A. Stephan, C. Grenzmann (2004), FuE- und Innovationsverhalten von KMU und Großunternehmen unter dem Einfluss der Konjunktur. Studien zum deutschen Innovationssystem Nr. 22-2004.

Rammer, C., V. Zimmermann, E. Müller, D. Heger, B. Aschhoff, F. Reize (2006), Innovationspotenziale von kleinen und mittleren Unternehmen, Baden-Baden.

Reize, F. (2007), Mittelstand im Konjunkturhoch - Defizite bei Innovationen, Frankfurt.

Ricardo, D. (1821), The Principals of Political Economy and Taxation, Nachdruck der Ausgabe von 1952, London.

Rottmann, H., G. Flaig (1999), Direkte und indirekte Beschäftigungseffekte von Innovationen. Eine empirische Paneldatenanalyse für Unternehmen des westdeutschen 
Verarbeitenden Gewerbes, pp. 149-166 in: V. Steiner, L. Bellmann, (Eds.), Qualifikation und Beschäftigungsdynamik, BeitrAb 229.

Rottmann, H., M. Ruschinski (1997), Beschäftigungswirkungen des technischen Fortschritts. Eine Paneldaten-Analyse für Unternehmen des Verarbeitenden Gewebes in Deutschland, Ifo-Studien - Zeitschrift für empirische Wirtschaftsforschung 43/I: 5577.

Schumpeter, J. A. (1912), Theorie der wirtschaftlichen Entwicklung - Eine Untersuchung über Unternehmensgewinn, Kapital, Kredit, Zins und den Konjunkturzyklus, Leipzig.

Stoneman, P. (1983), The economic analysis of technological change, Oxford.

Smolny, W., T. Schneeweis (1999), Innovation, Wachstum und Beschäftigung. Eine empirische Untersuchung auf der Basis des ifo Unternehmenspanels, Jahrbücher für Nationalökonomie und Statistik, 218 (3+4): 457-472.

Utterback, J.M., W.J. Abernathy (1975), A Dynamic Model of Process and Product Innovation, Omega: The international journal of Management Sciences 3, 639-655.

Welsch, J. (2006), Paradigmenwechsel beim Zusammenhang von Innovation und Beschäftigung? Wirtschaftsdienst 2006 / 12: 811-820.

Zimmermann, K. (1987), Innovation und Beschäftigung, S. 235 - 257 in: G. Bombach (Ed.), Arbeitsmärkte und Beschäftigung - Fakten, Analysen, Perspektiven, Tübingen.

Zimmermann, V. (2008), Die Wirkung verschiedener Arten von Innovationen auf die Beschäftigung in kleinen und mittleren Unternehmen, pp. 165-186 in: J. Merz, R. Schulte (Eds.), Neue Ansätze der MittelstandsForschung. CREPS-Schriftenreihe 4, Lit Verlag, Münster. 


\section{Appendix}

Table 2: Descriptive statistics for the explanatory variables used in the study

\begin{tabular}{|c|c|c|}
\hline & $\begin{array}{l}\text { Percentage / } \\
\text { Mean }\end{array}$ & Median \\
\hline Innovation activity & & \\
\hline $\begin{array}{l}\text { Innovation } \\
\text { Product innovation } \\
\text { Process innovation }\end{array}$ & $\begin{array}{l}55.2 \\
46.2 \\
34.3\end{array}$ & \\
\hline Gross value added at the industry level & & \\
\hline $\begin{array}{l}\text { Average change in gross value added (in \%) } \\
\text { Foreign turnover }\end{array}$ & 0.34 & 0.24 \\
\hline $\begin{array}{l}\text { Percentage of turnover earned abroad } \\
\text { Age of company }\end{array}$ & 7.9 & 0.0 \\
\hline $\begin{array}{l}\text { Age in years } \\
\text { Company size }\end{array}$ & 31.0 & 14 \\
\hline $\begin{array}{l}\text { Number of full-time employees } \\
\text { Legal form }\end{array}$ & 41.5 & 13.5 \\
\hline Region Limited liability & 10.6 & \\
\hline $\begin{array}{l}\text { Former East Germany } \\
\text { Subsidy status }\end{array}$ & 42.4 & \\
\hline $\begin{array}{l}\text { No subsidies received } \\
\text { Survey year (regarding the explanatory variables) }\end{array}$ & 31.3 & \\
\hline $\begin{array}{l}2003 \\
2005 \\
2006\end{array}$ & $\begin{array}{l}25.6 \\
39.5 \\
34.9\end{array}$ & \\
\hline
\end{tabular}


Table 3: Regression results for employee growth rates

\begin{tabular}{|c|c|c|c|c|c|c|}
\hline & \multirow[t]{2}{*}{$\begin{array}{l}\text { Least squares } \\
\text { regression }\end{array}$} & \multicolumn{5}{|c|}{ Quantile regressions } \\
\hline & & $\begin{array}{c}10 \% \\
\text { quantile }\end{array}$ & $\begin{array}{c}25 \% \\
\text { quantile }\end{array}$ & $\begin{array}{c}50 \% \\
\text { quantile } \\
\end{array}$ & $\begin{array}{c}75 \% \\
\text { quantile }\end{array}$ & $\begin{array}{c}90 \% \\
\text { quantile }\end{array}$ \\
\hline & $\begin{array}{c}\text { Coefficient } \\
\text { (robust t-value) }\end{array}$ & $\begin{array}{l}\text { Coefficient } \\
\text { (t-value) }\end{array}$ & $\begin{array}{l}\text { Coefficient } \\
\text { (t-value) }\end{array}$ & $\begin{array}{l}\text { Coefficient } \\
\text { (t-value) }\end{array}$ & $\begin{array}{l}\text { Coefficient } \\
\text { (t-value) }\end{array}$ & $\begin{array}{l}\text { Coefficient } \\
\text { (t-value) }\end{array}$ \\
\hline Innovation & $\begin{array}{r}1.894 \\
(4.95)\end{array}$ & $\begin{array}{r}0.774 \\
(2.3)\end{array}$ & $\begin{array}{r}0.932 \\
(3.12)\end{array}$ & $\begin{array}{r}0.943 \\
(6.14)\end{array}$ & $\begin{array}{r}1.846 \\
(5.27)\end{array}$ & $\begin{array}{r}1.973 \\
(3.63)\end{array}$ \\
\hline $\begin{array}{l}\text { Average gross value added } \\
\text { at the industry level (in \%) }\end{array}$ & $\begin{array}{r}0.277 \\
(3.41)\end{array}$ & $\begin{array}{r}0.481 \\
(7.71)\end{array}$ & $\begin{array}{r}0.462 \\
(8.43)\end{array}$ & $\begin{array}{r}0.186 \\
(6.53)\end{array}$ & $\begin{array}{r}0.270 \\
(4.07)\end{array}$ & $\begin{array}{r}0.442 \\
(4.18)\end{array}$ \\
\hline $\begin{array}{l}\text { (Average gross value } \\
\text { added at the industry } \\
\text { level) }\end{array}$ & -0.015 & -0.0 & -0.022 & & & 0.017 \\
\hline & $(-1.1)$ & $(-2.32)$ & $(-2.43)$ & $(-0.28)$ & $(-0.73)$ & $(-0.78)$ \\
\hline $\begin{array}{l}\text { Percentage of turnover } \\
\text { earned abroad }\end{array}$ & $\begin{array}{r}0.086 \\
(6.36)\end{array}$ & $\begin{array}{r}0.039 \\
(4.01)\end{array}$ & $\begin{array}{r}0.031 \\
(3.63)\end{array}$ & $\begin{array}{r}0.034 \\
(7.87)\end{array}$ & $\begin{array}{r}0.060 \\
(6.18)\end{array}$ & $\begin{array}{r}0.086 \\
(5.56)\end{array}$ \\
\hline Log (full-time equivalent) & $\begin{array}{r}-4.095 \\
(-19.62)\end{array}$ & $\begin{array}{r}0.334 \\
(2.48)\end{array}$ & $\begin{array}{l}-0.809 \\
(-6.89)\end{array}$ & $\begin{array}{r}-0.436 \\
(-6.7)\end{array}$ & $\begin{array}{r}-3.026 \\
(-18.64)\end{array}$ & $\begin{array}{r}-6.310 \\
(-20.39)\end{array}$ \\
\hline Log (company age) & $\begin{array}{l}-3.869 \\
(-5.69)\end{array}$ & $\begin{array}{r}0.596 \\
(0.77)\end{array}$ & $\begin{array}{l}-0.992 \\
(-1.48)\end{array}$ & $\begin{array}{l}-1.801 \\
(-5.11)\end{array}$ & $\begin{array}{l}-5.142 \\
(-6.15)\end{array}$ & $\begin{array}{r}-7.371 \\
(-5.6)\end{array}$ \\
\hline $\begin{array}{l}\text { Legal form: limited } \\
\text { liability }\end{array}$ & $\begin{array}{l}2.128 \\
(4.26)\end{array}$ & $\begin{array}{l}1.544 \\
(2.80)\end{array}$ & $\begin{array}{l}1.400 \\
(2.88)\end{array}$ & $\begin{array}{l}0.548 \\
(2.19)\end{array}$ & $\begin{array}{r}0.842 \\
(1.48)\end{array}$ & $\begin{array}{l}2.556 \\
(2.84)\end{array}$ \\
\hline $\begin{array}{l}\text { Region: former East } \\
\text { Germany }\end{array}$ & $\begin{array}{l}-0.831 \\
(-2.10)\end{array}$ & $\begin{array}{l}-0.510 \\
(-1.50)\end{array}$ & $\begin{array}{l}-0.694 \\
(-2.31)\end{array}$ & $\begin{array}{l}-0.330 \\
(-2.13)\end{array}$ & $\begin{array}{l}-1.429 \\
(-4.04)\end{array}$ & $\begin{array}{l}-1.630 \\
(-2.95)\end{array}$ \\
\hline $\begin{array}{l}\text { Subsidy status: no } \\
\text { subsidies received }\end{array}$ & $\begin{array}{l}-0.903 \\
(-2.17)\end{array}$ & $\begin{array}{l}-0.885 \\
(-2.55)\end{array}$ & $\begin{array}{l}-1.503 \\
(-4.88)\end{array}$ & $\begin{array}{l}-0.913 \\
(-5.76)\end{array}$ & $\begin{array}{l}-1.306 \\
(-3.61)\end{array}$ & $\begin{array}{l}-1.241 \\
(-2.20)\end{array}$ \\
\hline Dummy: 2005 survey & $\begin{array}{l}-4.221 \\
(-8.48)\end{array}$ & $\begin{array}{l}-0.265 \\
(-0.63)\end{array}$ & $\begin{array}{l}-0.815 \\
(-2.22)\end{array}$ & $\begin{array}{l}-1.015 \\
(-5.40)\end{array}$ & $\begin{array}{l}-3.622 \\
(-8.48)\end{array}$ & $\begin{array}{r}-7.261 \\
(-10.81)\end{array}$ \\
\hline Dummy: 2006 survey & $\begin{array}{l}-3.787 \\
(-7.42)\end{array}$ & $\begin{array}{r}0.472 \\
(1.08)\end{array}$ & $\begin{array}{l}-0.257 \\
(-0.68)\end{array}$ & $\begin{array}{l}-0.700 \\
(-3.60)\end{array}$ & $\begin{array}{l}-3.043 \\
(-6.88)\end{array}$ & $\begin{array}{l}-6.550 \\
(-9.49)\end{array}$ \\
\hline Constant & $\begin{array}{l}18.609 \\
(21.68) \\
\end{array}$ & $\begin{array}{l}-12.740 \\
(-24.54) \\
\end{array}$ & $\begin{array}{l}-1.698 \\
(-3.80) \\
\end{array}$ & $\begin{array}{r}2.535 \\
(10.41) \\
\end{array}$ & $\begin{array}{r}21.454 \\
(35.14) \\
\end{array}$ & $\begin{array}{r}45.491 \\
(39.57) \\
\end{array}$ \\
\hline $\begin{array}{l}\text { Number of observances } \\
R^{2} / \text { Pseudo } R^{2}\end{array}$ & $\begin{array}{l}12.095 \\
0.0793\end{array}$ & $\begin{array}{l}12.095 \\
0.0159\end{array}$ & $\begin{array}{l}12.095 \\
0.0146\end{array}$ & $\begin{array}{l}12.095 \\
0.0051\end{array}$ & $\begin{array}{l}12.095 \\
0.0508\end{array}$ & $\begin{array}{l}12.095 \\
0.1196\end{array}$ \\
\hline
\end{tabular}

Note: The Hubert method (1967) is used for calculating standard errors in the least squares regressions. 
Table 4: Regression results for employee growth rates under consideration of innovation type

\begin{tabular}{|c|c|c|c|c|c|c|}
\hline & \multirow[t]{2}{*}{$\begin{array}{l}\text { Least squares } \\
\text { regression }\end{array}$} & \multicolumn{5}{|c|}{ Quantile regressions } \\
\hline & & $\begin{array}{c}10 \% \\
\text { quantile }\end{array}$ & $\begin{array}{c}25 \% \\
\text { quantile }\end{array}$ & $\begin{array}{c}50 \% \\
\text { quantile }\end{array}$ & $\begin{array}{c}75 \% \\
\text { quantile }\end{array}$ & $\begin{array}{c}90 \% \\
\text { quantile }\end{array}$ \\
\hline & $\begin{array}{c}\text { Coefficient } \\
\text { (robust t-value) }\end{array}$ & $\begin{array}{l}\text { Coefficient } \\
\text { (t-value) }\end{array}$ & $\begin{array}{c}\text { Coefficient } \\
\text { (t-value) }\end{array}$ & $\begin{array}{c}\text { Coefficient } \\
\text { (t-value) }\end{array}$ & $\begin{array}{l}\text { Coefficient } \\
\text { (t-value) }\end{array}$ & $\begin{array}{c}\text { Coefficient } \\
\text { (t-value) }\end{array}$ \\
\hline Product innovation & $\begin{array}{r}0.880 \\
(2.28)\end{array}$ & $\begin{array}{r}0.554 \\
(1.39)\end{array}$ & $\begin{array}{r}0.405 \\
(1.41)\end{array}$ & $\begin{array}{r}0.495 \\
(3.03)\end{array}$ & $\begin{array}{l}1.062 \\
(2.67)\end{array}$ & $\begin{array}{r}0.869 \\
(1.49)\end{array}$ \\
\hline Process innovation & $\begin{array}{r}2.053 \\
(5.01)\end{array}$ & $\begin{array}{r}0.494 \\
(1.16)\end{array}$ & $\begin{array}{l}1.170 \\
(3.83)\end{array}$ & $\begin{array}{r}1.126 \\
(6.46)\end{array}$ & $\begin{array}{l}1.523 \\
(3.58)\end{array}$ & $\begin{array}{l}1.755 \\
(2.82)\end{array}$ \\
\hline $\begin{array}{l}\text { Average gross value added } \\
\text { at the industry level (in \%) }\end{array}$ & $\begin{array}{r}0.262 \\
(3.18)\end{array}$ & $\begin{array}{r}0.491 \\
(7.08)\end{array}$ & $\begin{array}{r}0.450 \\
(8.98)\end{array}$ & $\begin{array}{r}0.183 \\
(6.38)\end{array}$ & $\begin{array}{r}0.250 \\
(3.49)\end{array}$ & $\begin{array}{r}0.395 \\
(3.67)\end{array}$ \\
\hline $\begin{array}{l}\text { (Average gross value } \\
\text { added at the industry } \\
\text { level) }\end{array}$ & $\begin{array}{l}-0.013 \\
(-0.92)\end{array}$ & $\begin{array}{l}-0.034 \\
(-2.21)\end{array}$ & $\begin{array}{r}-0.021 \\
(-2.5)\end{array}$ & $\begin{array}{l}-0.001 \\
(-0.22)\end{array}$ & $\begin{array}{l}-0.004 \\
(-0.35)\end{array}$ & $\begin{array}{l}-0.012 \\
(-0.54)\end{array}$ \\
\hline $\begin{array}{l}\text { Percentage of turnover } \\
\text { earned abroad }\end{array}$ & $\begin{array}{r}0.083 \\
(6.18)\end{array}$ & $\begin{array}{r}0.039 \\
(3.54)\end{array}$ & $\begin{array}{r}0.034 \\
(4.26)\end{array}$ & $\begin{array}{r}0.033 \\
(7.47)\end{array}$ & $\begin{array}{r}0.054 \\
(5.16)\end{array}$ & $\begin{array}{r}0.087 \\
(5.60)\end{array}$ \\
\hline Log (full-time equivalent) & $\begin{array}{r}-4.129 \\
(-19.29)\end{array}$ & $\begin{array}{r}0.347 \\
(2.29)\end{array}$ & $\begin{array}{l}-0.900 \\
(-8.35)\end{array}$ & $\begin{array}{l}-0.470 \\
(-7.13)\end{array}$ & $\begin{array}{r}-3.045 \\
(-17.34)\end{array}$ & $\begin{array}{r}-6.333 \\
(-20.17)\end{array}$ \\
\hline Log (company age) & $\begin{array}{l}-3.689 \\
(-5.37)\end{array}$ & $\begin{array}{r}0.702 \\
(0.81)\end{array}$ & $\begin{array}{l}-0.603 \\
(-0.98)\end{array}$ & $\begin{array}{l}-1.623 \\
(-4.58)\end{array}$ & $\begin{array}{l}-5.155 \\
(-5.75)\end{array}$ & $\begin{array}{l}-7.153 \\
(-5.36)\end{array}$ \\
\hline $\begin{array}{l}\text { Legal form: limited } \\
\text { liability }\end{array}$ & $\begin{array}{r}1.983 \\
(3.96)\end{array}$ & $\begin{array}{l}1.487 \\
(2.44)\end{array}$ & $\begin{array}{l}1.256 \\
(2.85)\end{array}$ & $\begin{array}{r}0.393 \\
(1.57)\end{array}$ & $\begin{array}{r}0.819 \\
(1.35)\end{array}$ & $\begin{array}{r}2.369 \\
(2.60)\end{array}$ \\
\hline $\begin{array}{l}\text { Region: former East } \\
\text { Germany }\end{array}$ & $\begin{array}{l}-0.824 \\
(-2.05)\end{array}$ & $\begin{array}{l}-0.470 \\
(-1.24)\end{array}$ & $\begin{array}{l}-0.610 \\
(-2.22)\end{array}$ & $\begin{array}{l}-0.364 \\
(-2.34)\end{array}$ & $\begin{array}{l}-1.450 \\
(-3.95)\end{array}$ & $\begin{array}{l}-1.634 \\
(-2.91)\end{array}$ \\
\hline $\begin{array}{l}\text { Subsidy status: no } \\
\text { subsidies received }\end{array}$ & $\begin{array}{l}-0.872 \\
(-2.08)\end{array}$ & $\begin{array}{l}-0.993 \\
(-2.57)\end{array}$ & $\begin{array}{l}-1.551 \\
(-5.53)\end{array}$ & $\begin{array}{l}-0.913 \\
(-5.73)\end{array}$ & $\begin{array}{l}-1.267 \\
(-3.27)\end{array}$ & $\begin{array}{l}-1.196 \\
(-2.09)\end{array}$ \\
\hline Dummy: 2005 survey & $\begin{array}{l}-4.127 \\
(-8.09)\end{array}$ & $\begin{array}{l}-0.344 \\
(-0.73)\end{array}$ & $\begin{array}{l}-0.646 \\
(-1.91)\end{array}$ & $\begin{array}{l}-0.948 \\
(-4.98)\end{array}$ & $\begin{array}{l}-3.364 \\
(-7.30)\end{array}$ & $\begin{array}{r}-7.506 \\
(-10.97)\end{array}$ \\
\hline Dummy: 2006 survey & $\begin{array}{l}-3.840 \\
(-7.34)\end{array}$ & $\begin{array}{r}0.301 \\
(0.61)\end{array}$ & $\begin{array}{l}-0.231 \\
(-0.66)\end{array}$ & $\begin{array}{l}-0.736 \\
(-3.74)\end{array}$ & $\begin{array}{l}-2.919 \\
(-6.12)\end{array}$ & $\begin{array}{l}-7.004 \\
(-9.93)\end{array}$ \\
\hline Constant & $\begin{array}{l}18.585 \\
(21.31) \\
\end{array}$ & $\begin{array}{l}-12.658 \\
(-21.98) \\
\end{array}$ & $\begin{array}{l}-1.701 \\
(-4.17) \\
\end{array}$ & $\begin{array}{r}2.55 \\
(10.43) \\
\end{array}$ & $\begin{array}{l}21.422 \\
(32.78) \\
\end{array}$ & $\begin{array}{r}45.714 \\
(39.34) \\
\end{array}$ \\
\hline $\begin{array}{l}\text { Number of observances } \\
R^{2} / \text { Pseudo } R^{2}\end{array}$ & $\begin{array}{l}11.857 \\
0.0789\end{array}$ & $\begin{array}{l}11.857 \\
0.0162\end{array}$ & $\begin{array}{l}11.857 \\
0.0153\end{array}$ & $\begin{array}{l}11.857 \\
0.0056\end{array}$ & $\begin{array}{l}11.857 \\
0.0502\end{array}$ & $\begin{array}{l}11.857 \\
0.1184\end{array}$ \\
\hline
\end{tabular}

Note: The Hubert method (1967) is used for calculating standard errors in the least squares regressions. 